\title{
Remodelling media: The urgent search for new media business models
}

\author{
Jim Macnamara \\ University of Technology Sydney
}

\begin{abstract}
One of the most contentious and pressing issues in relation to media in the early $21^{\text {st }}$ century is identifying viable business models, with widespread reports that $20^{\text {th }}$ century business models underpinning press, radio and television are collapsing because of 'audience fragmentation' driven by an ever-widening range of choice in media content and sources on the internet. Some scholars, media proprietors and content producers see announcements by Rupert Murdoch's News Corporation and the New York Times that they will increasingly charge for news and other content as a harbinger of the new mediascape and a resolution to media decline. However, a number of reader surveys and industry analyses warn that many contemporary media users will not pay for content and will further abandon traditional media if 'paywalls, ${ }^{1}$ are erected. A range of other potential business models are being touted in business and industry circles, but remain underresearched and under-explored in scholarly literature. This article reviews scholarly studies that do exist, as well as business and industry studies and media data, to identify the range of options for funding journalism and other media content in future. Identification of sustainable media business models is an urgent priority, as continuing decline in audiences and collapse of media organisations pose a major threat to journalism and society, with scholars agreeing that further erosion of quality journalism threatens democracy. Future media business models also have major implications for the advertising industry and a wide range of content producers.
\end{abstract}

\section{Introduction}

A growing body of statistics and worldwide media headlines identify a serious problem facing media in the early $21^{\text {st }}$ century - a problem that is proving fatal for some media organisations and which could threaten the future of journalism and functioning of the largely mediated public sphere central to contemporary democracies. US Audit Bureau of Circulations statistics show that total daily American newspaper circulation has declined by almost a quarter since its peak of 63.3 million in 1984 to 48.6 million in 2008 (Newspaper Association of America, 2008), with a further fall of 10.6 per cent in 2009 to around 44 million (Pérez-Peña, 2009) (See Table 1).

News Corporation, one of the world's largest and most successful media empires owned by Rupert Murdoch, reported a loss of US\$3.38 billion in the year ended 30 June 2009 (Business Week Stock Quote \& Company Profile, 2010). The Chicago-based Tribune Company, owner of the Chicago Tribune as well as the Los Angeles Times filed for bankruptcy protection in December 2008, and in August 2009, Freedom Communications in California, owner of the Orange County Register and 30 other newspapers with more than 8,000 staff followed suit. Editor and Publisher reported that Freedom was the $10^{\text {th }}$ newspaper publisher in the US to collapse in 12 months (Liedtke, 2009), and credit rating agency Fitch warned that a number of major US cities could be without a daily newspaper by 2010 (Foley, 2008). Even the highly-regarded Christian Science Monitor was forced to cut its production from daily to weekly (Nichols \& McChesney, 2010), and a PriceWaterhouseCoopers report on newspaper business models says that many other US newspapers are in the midst of substantial restructuring (2009, p. 12). 


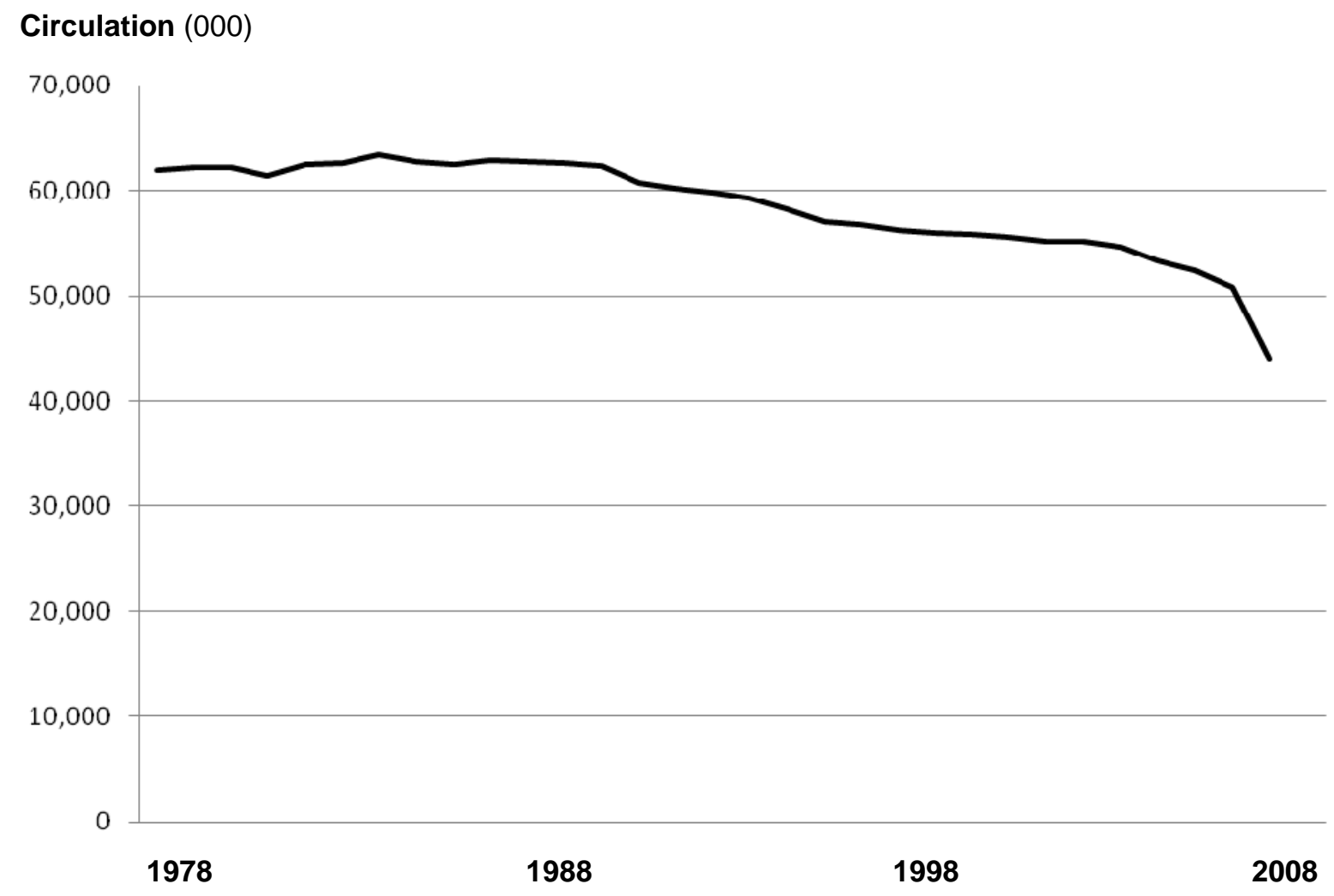

Figure 1. US daily newspaper circulation 1978-2008

Source: Newspaper Association of America (2008) and Pérez-Peña (2009)

Similarly in the UK, Audit Board of Circulation statistics show "circulation falling across the board" for many years (Este et al., 2008, pp. 7-8), and the trend is escalating. In its 'Newspaper DeathWatch' section, Crikey reported in May 2009 that all of the UK's main newspaper titles were losing circulation including The Sunday Independent which fell an alarming 27 per cent in the year to April 2009 (Dyer, 2009, paras 1-3). PriceWaterhouseCoopers supports predictions that half of the 20,000 jobs in the UK newspaper industry will be lost in the next five years (2009, p. 12).

Audit Bureau of Circulations data for the fourth quarter of 2009 showed all except two of Australia's national and leading metropolitan newspapers had significant circulation falls compared with the previous year, some by more than 10 per cent in one year (See Table 2). This trend is continuing with a further three per cent fall in newspaper sales in the first three months of 2010, according to the Audit Bureau of Circulations (Kruger, 2010, para. 2).

As well as turning away from newspapers, Australian metropolitan TV network viewing was down five per cent in the six months July-December 2009 (Free TV Australia, 2010). The youth market in particular is abandoning broadcast content. John Pavlik reports that listenership of radio among teenagers has fallen 20 per cent in the US since 1996 (2008, p. 62). Roy Morgan ratings data show similar declines in Australia (Roy Morgan Research, 2007). The Australian Communications and Media Authority (2007) also reports that television viewing is declining among young people and their media consumption is increasingly turning to the internet.

Referred to in the industry as 'audience fragmentation' or 'disaggregation', this breakdown of large mass audiences of mass media is having a 'double whammy' effect on the dominant commercial media business model, advertising. As Henry Jenkins warns, "monolithic blocks 
of eyeballs are gone” (2006, p. 66), resulting in both advertising volume and rates falling. Table 2 shows total US newspaper advertising revenue from both print and online editions, illustrating that growth in online newspaper advertising has been insufficient to offset declines in print advertising revenue, resulting in an overall decline of 42.9 per cent since 2004. It is likely that part of the losses in circulation and advertising revenue in 2009 are cyclical effects of the global financial crisis. However, the long-standing trends in circulation and advertising revenue in US newspapers, and similar decline in the UK and other markets including Australia (Este et al., 2008; Free TV Australia, 2010), as well as a steady loss of broadcast audiences and advertising revenue, illustrate the need for structural reform in media organisations and diversification beyond advertising based on audience size. As The Guardian's digital media director Emily Bell warned at a media 'think tank' in 2008: "this is systematic collapse - not just a cyclical downturn” (Bell, 2008).

Table 1. Audited Australian newspaper circulation Q4 2009 compared with Q4 2008

\begin{tabular}{lrrr}
\hline Title & Q4 2008 & Q4 2009 & \% change \\
\hline Australian Financial Review (Mon-Fri) & 86,158 & 77,470 & $-10.08 \%$ \\
Australian Financial Review (Sat) & 84,528 & 93,800 & $-9.88 \%$ \\
The Australian (Mon-Fri) & 137,000 & 131,246 & $-4.20 \%$ \\
Weekend Australian & 309,000 & 300,941 & $-2.61 \%$ \\
Sunday Telegraph & 653,000 & 632,009 & $-3.21 \%$ \\
Sunday Herald Sun & 606,500 & 601,000 & $-0.91 \%$ \\
Sunday Mail & 551,271 & 525,477 & $-4.68 \%$ \\
Herald-Sun (Mon-Fri) & 515,500 & 514,000 & $-0.29 \%$ \\
Herald-Sun (Sat) & 502,000 & 503,000 & $+0.20 \%$ \\
Sun-Herald & 473,469 & 442,357 & $-6.57 \%$ \\
Daily Telegraph (Mon-Fri) & 369,000 & 359,171 & $-2.66 \%$ \\
Sydney Morning Herald (Sat) & 360,200 & 353,878 & $-1.76 \%$ \\
Age (Sat) & 296,750 & 291,000 & $-1.94 \%$ \\
Courier Mail (Sat) & 296,054 & 288,924 & $-2.41 \%$ \\
Sunday Age & 227,100 & 228,600 & $+0.66 \%$ \\
Courier Mail (Mon-Fri) & 215,383 & 211,230 & $-1.93 \%$ \\
Sydney Morning Herald (Mon-Fri) & 211,370 & 211,006 & $-0.17 \%$ \\
Age (Mon-Fri) & 204,200 & 202,100 & $-1.03 \%$ \\
West Australian (Mon-Fri) & 192,964 & 188,211 & $-2.46 \%$ \\
\hline
\end{tabular}

Source: Audit Bureau of Circulations (2010)

Table 2. Total US newspaper print and online advertising revenue

\begin{tabular}{lllllll}
\hline Year & $\begin{array}{l}\text { Total print } \\
\text { advertising } \\
\text { (USD millions) }\end{array}$ & $\begin{array}{l}\% \\
\text { change }\end{array}$ & $\begin{array}{l}\text { Total online } \\
\text { advertising } \\
\text { (USD millions) }\end{array}$ & $\begin{array}{l}\% \\
\text { Change }\end{array}$ & $\begin{array}{l}\text { Total of all } \\
\text { Advertising } \\
\text { (USD millions) }\end{array}$ & $\begin{array}{l}\text { Total \% } \\
\text { change }\end{array}$ \\
\hline $\mathbf{2 0 0 4}$ & $\$ 46,703$ & $+3.9 \%$ & $\$ 1,541$ & $+26.7 \%$ & $\$ 48,244$ & $+4.5 \%$ \\
$\mathbf{2 0 0 5}$ & $\$ 47,408$ & $+1.5 \%$ & $\$ 2,027$ & $+31.5 \%$ & $\$ 49,435$ & $+2.5 \%$ \\
$\mathbf{2 0 0 6}$ & $\$ 46,611$ & $-1.7 \%$ & $\$ 2,664$ & $+31.5 \%$ & $\$ 49,275$ & $-0.3 \%$ \\
$\mathbf{2 0 0 7}$ & $\$ 42,209$ & $-9.4 \%$ & $\$ 3,166$ & $+18.8 \%$ & $\$ 45,375$ & $-7.9 \%$ \\
$\mathbf{2 0 0 8}$ & $\$ 34,740$ & $-17.7 \%$ & $\$ 3,109$ & $-1.8 \%$ & $\$ 37,848$ & $-16.6 \%$ \\
$\mathbf{2 0 0 9}$ & $\$ 24,821$ & $-28.6 \%$ & $\$ 2,743$ & $-11.8 \%$ & $\$ 27,564$ & $-27.2 \%$ \\
\hline
\end{tabular}

Source: Newspaper Association of America (2010) 
These trends, some evident over more than 20 years as shown graphically in Figure 1, also suggest that the media industry has been slow to react and change. A Deloitte Technology, Media and Telecommunication report on 'Television Networks in the $21^{\text {st }}$ Century' published five years ago spelled out a need for the industry to find alternative business models (Deloitte, 2005, p. 7). KPMG also warned some years ago that 'old' media must rethink their business models" (2007, p. 4). Notwithstanding, John Pavlik concluded in his 2008 text Media in the Digital Age that "few media organisations have settled on a viable long-term strategy for making money in a sustainable fashion" (2008, p. 173). James Curran describes media organisations as being in "ostrich-like denial” (2010, p. 467) in claiming that they and journalism are negotiating a "process of well managed transition” (p. 465).

Rupert Murdoch (2005) has admitted that he and his massive media empire were slow to recognise the importance of the internet. In his 2009 A.N. Smith Memorial Lecture in Journalism, managing director of the ABC, Mark Scott said: "We have reached a point that we should perhaps have seen was coming, yet largely we did not” (Scott, 2009). Worse, many media industries and organisations have responded defensively and defiantly clung to traditional practices. For instance, the response of the music industry to development of fast, low-cost internet distribution of products by services such as Napster, launched in 1999 by Northeastern University student Shawn Fanning, was to stop the development through legal action. Subsequently, the Record Industry Association of America (RIAA) also launched lawsuits against individual internet music downloaders. One celebrated case involved legal action against 12-year-old Brianna LaHara who became a 'poster girl' for a public backlash against the industry after the story was splashed across the front page of the New York Times (Montgomery, 2009, p. 1). The industry was not doing itself any favours. While content creators have moral and legal rights to earn income from their work and investment, the industry failed to recognise that music buyers had become tired of products and distribution methods that forced them to buy 20 or more songs, many of which they did not want. Until recently, the music industry continued to use distribution methods that were developed following the invention of the phonograph and vinyl records almost a century before. The film industry also has sought to enforce its copyright and traditional channels of distribution in similar ways, with groups such as the Motion Picture Association of America launching global anti-piracy campaigns (Crawford, 2005, p. 31).

Also John Pavlik points out that media organisations, particularly news companies and departments, have not invested sufficiently in research and development to expand or update their product line over recent decades (2008, p. 20). Pavlik estimates that many news media have invested less than one per cent of their operating budgets in $R \& D$ to develop new products and new business models. Because of regulation of broadcasting which has restricted the number of broadcasting licences to cosy cartels in many markets (e.g. three commercial TV networks in Australia), monopoly and oligopoly market positions of newspaper conglomerates, and mass communication technologies, competition has been limited and many media organisations became complacent. For 50 years since 74 per cent of Americans and almost as many Australians clustered around TV sets to watch I Love Lucy every Sunday night (Anderson, 2006, p. 29) media have enjoyed protectionism and it looked like the halcyon days would never end. But end they have.

As a result of lack of research and development, many media products lack innovation. Newspaper formats developed in the $19^{\text {th }}$ century persist, with many still produced on thin, poor-quality paper, often in cumbersome sizes, and with Saturday editions containing weighty specialist sections of information and classified advertising that are mass distributed even though many readers are not in the market to buy a commercial building, or a home, or car. Philip Meyer points out that "sending everything to everybody was a response to the 
industrial revolution which rewarded economies of scale” (2008, para. 16). Today, such production and distribution methods are financially and environmentally questionable.

Traditional media also have not responded well to new forms of media that have entered the market. CEO of News Limited in Australia, John Hartigan (2009) told the National Press Club in 2009 that blogs are "parasites" regurgitating and commenting on content researched by major media organisations, and he described blog content as "something of such limited intellectual value as to be barely discernible from massive ignorance". While research identifies intermediation and remediation between traditional and social media - in both directions - (e.g. Chen \& Walsh, 2008; Macnamara, 2008), major news stories are increasingly broken by citizen and social media. Examples range from the Bill ClintonMonica Lewinsky scandal exposed by The Drudge Report and the 'outing' of veteran CBS newscaster and 60 Minutes reporter Dan Rather's false reporting of President George Bush's military record by FreeRepublic.com in 2004 (Rheingold, 2008, p. 103) to the first news of Michael Jackson's death reported by the celebrity gossip Web site, TMZ (2009).

The cost of failing to recognise the potential and public demand for new forms of content and distribution methods has been that media organisations have not developed new products tailored to the Web 2.0 environment of social media and social networks and the changing cultural economy (Macnamara, 2010). As illustrated by circulation, audience and advertising sales data, there is now an urgent need to find sustainable business models to support news, current affairs, and other forms of content in what Mark Poster (1995) identified as the Second Media Age.

\section{Methodology}

This discussion presents a critical analysis of potential media business models based on literature review spanning both scholarly and industry research and reports. It is recognised, as Van Dijck and Nieborg (2009, p. 856) note, that many business and industry analyses and manifestos are "pamphlets written by business gurus" who are "consultants in the business of selling their high-priced advice". However, extending the lens beyond scholarly research is necessary for two reasons. First, even though the future of quality journalism and the major site of the public sphere in contemporary democracies are threatened by a continuing decline in news media, there is a paucity of scholarly research in relation to new business models (Wang, 2009, p. 110). This is not to deny some valuable studies including those undertaken by the University of California, Berkeley Graduate School of Journalism and the University of Southern California Annenberg School for Communication which jointly house the Knight Digital Media Center, and the very specific New Business Models for News Project at City University of New York (CUNY) Graduate School of Journalism. However, in many cases examination of business models for media has fallen into the cracks between faculties of business and arts and humanities where journalism, advertising and media studies are traditionally located. Second, even when it is undertaken, the nature of scholarly research means that there is often a significant lag in its publication which limits its ability to inform discussion on dynamic issues.

While literature review is traditionally focussed on scholarly research, in this instance extensive literature review was undertaken of substantial industry publications and reports such as those of leading business and management consulting firms including Booz Allen Hamilton, Boston Consulting Group, Deloitte, KPMG and PriceWaterhouseCoopers, and media industry data and surveys such as those of Nielson Research, Roy Morgan, the Newspaper Association of America, and the World Association of Newspapers. Such an approach is necessary to gain an understanding of commercial, industrial and political 
perspectives as well as disciplinary, philosophical and moral issues involved in the structure and operation of media in liberal (and/or neo-liberal) capitalist societies.

This analysis is framed within a cultural economy perspective which seeks to integrate the interests of culture, society and the economy (Anheier \& Raj Isar, 2008; du Gay \& Pryke, 2000). While acknowledging divergent ideological and economic interests that are explored through political economy and cultural studies critiques of media, the purpose here is to focus on the urgent short-term imperative of maintaining independent media operating within established liberal capitalism that characterises Australia, the US, UK and many other major developed countries. Longer-term analysis and research could usefully consider alternative models based on political and economic change.

\section{Analysis}

Head of the media research program at Goldsmith College at the University of London, James Curran (2010) has provided a useful overview of current debate about future media directions and business models. He has identified four discourses which he described as: (1) "continuity" characterised by media proprietor survivalism and "ostrich-like denial"; (2) a "crisis of journalism" based on journalists' anxiety and pessimism; (3) "a cleansing purgative" in the eyes of "gleeful millenarians" who see a collapse of traditional media models as an opportunity for change; and (4) "renaissance" based on transformist views of liberal journalism and media academics who optimistically anticipate a new media world of 'citizen journalism' and 'network journalism' (Curran, 2010, pp. 464-470). Originally presented as a plenary paper to a Future of Journalism conference at Cardiff, Wales in September 2009, Curran's four positions were summarised in a conference report by the Canadian Journalism Project (2009) as "boisterous survivalism among industry leaders, gleeful apocalypticism among those disenchanted with the atrophy of the Fourth Estate, a panglossian optimism among academics, and an anxious overwhelmed sense among journalists who fear they might be witnessing their profession’s extinction” (para. 2).

Evidence of these views is readily found in industry and scholarly discussions. For example, "ostrich-like denial" is particularly evident in bullish statements made by Australian publishers and media spokespersons. The Sydney Morning Herald reported in mid-2009 that "Australia's four largest newspaper publishers have gone on the offensive against those predicting the death of the industry, saying their combined advertising sales fell less than one per cent last year and predicting a rebound when the economy recovers" (Steffens, 2009, para. 1). Newspapers Work, the marketing body of the newspaper industry described 2009 Audit Bureau of Circulations statistics shown in Table 1 as "firm", and blamed falls on "a patchy economy, skittish consumer behaviour and rising interest rates" ("National newspapers in biggest ever decline”, 2010).

Journalists' anxiety and fears are sustained and exacerbated by increasing redundancies and media closures. Despite its stated optimism about the future, Australasia's largest media group, Fairfax Media cut 550 jobs from its publications in Australia and New Zealand in 2008 - the group's third round of redundancies in three years (Steffens, 2008). The Web site which monitors journalists' jobs, Paper Cuts (2008), estimates that 15,554 journalists' jobs were lost in the US in 2008 and a similar number disappeared in 2009. Mark Deuze (2007) says bluntly in his text Media Work: "journalism as it is, is coming to an end" (p. 141), and he predicts increased precariousness and instability for staff of media organisations - what he refers to as "precarity" - although he does advocate an adaptive sustainable freelance model. 
Alongside what some see as a 'head in the sand' approach and pessimistic discourses of mainstream media decline or even collapse, a discourse of new age optimism has emerged among some academics and a number of industry 'gurus' and consultants. Noteworthy examples of new age manifestos include the best-seller by Christopher Locke and his colleagues, A Cluetrain Manifesto: The End of Business as Usual (Locke, Levine, Searles \& Weinberger, 2000) and Tapscott and Williams' (2006) widely-cited text Wikinomics which proposed "co-creation" through collaboration harnessing Web $2.0^{2}$ as a new business model. Other recent advocates of emergent business models contributing to what José Van Dijck and David Nieborg (2009, p. 870) call a largely uncritical "celebratory rhetoric” include Henry Jenkins (2006) in Convergence Culture; Chris Anderson (2006) in The Long Tail; and Charles Leadbeater (2007 in We-Think: Why Mass Creativity is the Next Big Thing.

Some business scholars such as University of Michigan Business School professors, C. K. Prahalad and Venkat Ramaswamy (2004) have supported popular rhetoric of Web 2.0 business models saying the conventional hierarchal business model which clearly distinguished producers and 'consumers' is increasingly being replaced by the a 'co-creation model'. However, exactly how Web 2.0 'co-creation' and collaborative models can be monetised in a consistent and generalised way remains ill-defined. Hand in hand with cocreation and user-generated content (UGC) in the Web 2.0 environment goes open free sharing of content, leading to a culture of mash-ups, remix, and file sharing that collides with established copyright which is foundational to traditional business models.

In this journal, Jing Wang has recently explored some 'post-advertising paradigms', examining three experimental user-generated content media projects - Magnatune and ccMixer in the US and Witkey in China (Wang, 2009). Magnatune is an open music platform founded by John Buckman in the US which offers users the chance to try before they buy. Novel features of the business model are that it allows users to pay either a "suggested" price of $\$ 8$ or a "minimum" price of $\$ 5$, and to share downloaded music with up to three other people for free. Interestingly, Wang reports that the average income per download is $\$ 8.93$ which seems to vindicate Buckman's belief that people will respond to a 'give as well as take' approach, and the latter feature uses viral marketing to support the third prong of the business model. That is, a large part of Magnatune's income is derived from selling licences for commercial use such as in movies. The more popular music is, the more it is in demand for movies and other commercial uses and the more commercial users will pay. So offering product free in one space can drive up revenue in another.

Lawrence Lessig, well-known for his advocacy for Creative Commons open licensing, founded ccMixter as a Web-based music remixing tool before selling it. Lessig demanded that the new owners maintained the site advertising free and access free. They also allegedly make money from the site through music branding opportunities offered to companies who want to access the 120,000 regular users of the site. However, Wang points out that ccMixter and Magnature operate in "post-affluent societies where artists can afford to contribute to the Creative Commons and where consumers can support their favourite artists altruistically" (2009, p. 117). She argues that such business models cannot be generally applied. Supporting this argument, she points out that Witkey is a Chinese online knowledge-sharing environment in which netizens offer solutions, ideas, and perform small tasks for cash rewards. These range from designing a logo to naming stores and newborns. In essence, Witkey's contributors are dedicated 'moonlighters' working for a bit of extra cash which makes the model not unlike existing business models.

Wang concludes that there has been "a lot of hype about UGC" (p. 114), and adds that many of the initiatives so far are "old wine in a new bottle" - for example, professionally produced 
content is replaced with user-generated content distributed virally, but the result is still advertising (p. 115). She reports that industry observers cite how big businesses have used new media to 'revolutionise' their marketing strategies, but asks "is it a real revolution?" Wang goes on to point out that many of the so-called business models involving Web 2.0 social media and social networks remain predominantly centred on outbound communication targeting 'consumers' and most content remains proprietary behind 'walled gardens, 3 (Wang, 2009, p. 115).

\section{Potential new media business models}

A number of options for the future are under discussion to varying degrees in the industry and in research studies, although some are gaining more attention than others. This discussion seeks to critically analyse the major alternative business models being presented, as well as shed light on others relegated to the shadows of industry gloom.

\section{Slash and burn approach}

While not a sustainable business model, it is necessary to note that pessimistic scenarios combined with lack of vision have led to a reactive approach by some media organisations to address the decline in audiences and revenue. A 2009 PriceWaterhouseCoopers study concluded that newspaper publishers have responded to the economic downturn by increasing their focus on cost reduction (2009, p. 4). A number of broadcast networks are doing likewise. However, while minimising costs is one important element of maintaining profitability, a business model it does not make. To the contrary, severe cost-cutting can damage media organisations in the longer term. For example, cutting costs usually reduces funding for research and development. Once investment in new products and services stops or is further curtailed, innovation is lost and the organisation's long-term future becomes more precarious than ever.

PriceWaterhouseCoopers comments that some media are indeed adopting multiple platforms and new technologies as channels for content distribution in order to reach their audiences. However, the firm's 2009 report on media Moving into Multiple Business Models concludes that "many have still to fully review their existing business models to take full advantage of the innovation in the marketplace and the demands of consumers" (PriceWaterhouseCoopers, 2009, p. 4).

\section{Charging for content - the push for paywalls}

Charging for content went to the top of the list of potential media business models being discussed in January 2010 with two significant developments. In the first, the publisher of the New York Times, Arthur Sulzberger Jr., announced that from January 2011 the prestigious publication known as 'the 'Grey Lady' would start charging for content above and beyond the cover price which meets only a small proportion of newspaper costs. While details are still becoming available, the approach announced is what is termed a 'metered' model, similar to that already in place at the London Financial Times in which subscribers to the print edition retain unlimited free online access, and online only readers are able to view a certain number of articles each month for free before hitting the paywall. However, adoption of even this limited model by the New York Times is seen as highly significant as the newspaper is regarded as a bastion of global media.

This is not the first attempt by the New York Times to charge for content. In September 2005, the newspaper introduced TimesSelect which charged US\$49.95 a year, or US\$7.95 a month, for online access to the newspaper's columnists and archives. By 2007, TimesSelect had gained 227,000 subscribers and was earning US\$10 million a year in subscriptions which 
sounds successful. However, in September 2007, the New York Times pulled down the paywall and made all content including its extensive archives free (Pérez-Peña, 2007). Senior vice president and general manager of TimesSelect, Vivian Schiller, was reported as saying that "projections for growth of the subscriber were low compared to the growth of online advertising”. The 227,000 subscribers gained represented only 28.8 per cent of the Times' total readership of 787,000 at the time (Pérez-Peña, 2007).

The second major impetus for paywalls occurred when Rupert Murdoch announced that News Corporation will progressively introduce charges for accessing the content of its titles worldwide (World Association of Newspapers, 2010, p. 5). Editor of the Daily Mirror in the UK, David Banks, is typical of media operators who are watching Rupert Murdoch closely. In a guest lecture at the University of Sunderland in late 2009, Banks said "everybody talks about paying to break through the paywall. I don't know anyone who quite knows how Rupert plans to do this. Nobody talks about it, they just say 'Oh yeah, if Rupert says it then it'll work”. Nevertheless, significantly, Banks expressed reservations about whether widely applied media paywalls will work (Bailly, 2009).

News Corporation's Wall Street Journal which began charging for content in 1996, the UK's leading business newspaper The Financial Times and Australia's Australian Financial Review are frequently cited as successful examples of charging for content. However, not all agree that paid content is the way to go. Chief Operating Officer of News Corporation, Chase Carey, told a newspaper editors forum in 2009 that he was unhappy with the Wall Street Journal's online paid content strategy despite it being one of the few profitable and successful paywalls. Carey pointed out cracks in the wall which have allowed users to read the newspapers' online content for free through a Google search, while readers who go directly to the site have to pay (Bailly, 2009). Since, Rupert Murdoch has threatened to block Google's search engine from accessing News Corporation's content (Wall, 2009). Technically this can be done quite easily (e.g. by installing a file such as robots.txt into a media site which tells a search engine Web crawler not to index a certain page). Microsoft has reportedly seized the opportunity as a way of regaining ground against its nemesis Google and allegedly announced that its search engine Bing will respect News Corporation's paywall provided the company blocks Google (Wall, 2009).

However, many hold moral reservations about the approach, suggesting that it represents a major extension and tightening of copyright which is already being cited as overly restrictive (e.g. Lessig, 2001, 2004), It also flies in the face of changing attitudes towards content in Web 2.0 culture. Following News Corporation's January 2010 announcement of its paywall plans, news executive producer of nineMSN, Hal Crawford said on the company's blog that "Murdoch's move represents a big threat to freedom" and announced that nineMSN would continue providing news for free (Crawford, 2009).

Others also argue against paywalls on practical business grounds. For instance, internet games entrepreneur, Jon Radoff ${ }^{4}$, cites New Zealand's National Business Review as an example of paywalls not working and the damage that can be done by introducing payment for content. Nielsen Research data shows NBR was a successful national newspaper up until April 2009 when it introduced a paywall. After the paywall was introduced, National Business Review's readership fell by almost half (Radoff, 2009). In the US, the Los Angeles Times (owned by the Tribune company which is now in Chapter 11) introduced charging for content in its arts section in 2005, but quickly dropped the scheme after a sharp fall in Web visitors (Pérez-Peña, 2007). The Altantic (formerly The Atlantic Monthly), one of a handful of US publications charging for content, also dropped its paywall in 2008, despite a prestigious 
reputation built over more than 150 years since its foundation in 1857 ("The Atlantic drops pay wall, 2008).

In Australia and the UK in particular, fee-based news faces a major challenge because of the existence of national public funded media networks, the ABC and BBC, which under their respective charters are bound to continue offering free content. Managing director of the ABC, Mark Scott, has expressed doubt that people are prepared to pay for news media content online and in his A. N. Smith Memorial Lecture in Journalism in October 2009, significantly titled 'The fall of Rome: Media after empire', reaffirmed that ABC content will remain free (Scott, 2009). Commercial media paywalls in the UK and Australia may simply drive up traffic to the BBC and $\mathrm{ABC}$.

A number of academic and industry studies indicate severe limitations to the market acceptance of paywalls. Media consultancy Oliver \& Ohlbaum conducted a survey of media users in the UK in late 2009 which found that most media users are likely to migrate away from news sources that introduce charging for content to other free sources. In a report of the study, The Economist referred to this as the "promiscuity problem", reporting that "when it comes to online news, Britons are shamelessly promiscuous" ("The promiscuity problem”, 2009). A survey by Nielson Research in Australia in late 2009 also reported a lack of brand loyalty online which suggests that media users will migrate away from sites that charge for content to free sites (as cited in Day, 2009).

Scholarly research that is available supports this view. A detailed study by the Australian Research Council Centre of Excellence for Creative Industries and Innovation at Swinburne University's Institute for Social Research carried out as part of the World Internet Project asked 800 Australian internet users in late 2009 how much they would be prepared to pay to read an online newspaper, given that a daily print newspaper costs around $\$ 1.50$. The survey found that over 70 per cent of Australians say they will not pay anything at all for news online. Importantly, the survey found that 76 per cent of those under 24 years of age say they will not pay for news online - suggesting that paywalls will exacerbate mainstream media problems in future (Simons, 2010).

PriceWaterhouseCoopers has released a major study carried out in association with the World Association of Newspapers, Moving into Multiple Business Models: Outlook for Newspaper Publishing in the Digital Age, based on an online survey of 4,900 media users in seven countries which also reports that "on average, respondents expressed no willingness to pay for general news and background information on e-paper or mobile devices" (2009, p. 21). People with particular interest in financial content and sports express the highest willingness to pay for content online, according to PriceWaterhouseCoopers (2009, p. 22). The study also reported as one of its major conclusions that consumers place high value on the deep insight and analysis provided by journalists over and above general or breaking news stories (p. 4). "Consumers see breaking news and general interest news as commodities, but there is always a market for high value online content in specific topics", the PWC report concluded (p. 4). Another significant finding is that those who read long articles online are more likely to pay (Simons, 2010). These findings offer some insights into specialist types of content that may attract paying readers and viewers.

Findings of a survey of 5,083 people in nine countries by the Boston Consulting Group in 2009 were slightly more positive, but still guarded, indicating that consumers are prepared to pay from US\$3 a month in the US and Australia up to US\$7 a month in Italy (Boston Consulting Group, 2009a, p. 3). Boston Consulting Group senior partner and head of the firm's global media group, John Rose, said "the good news is that, contrary to conventional 
wisdom, consumers are willing to pay for meaningful content. The bad news is that they are not willing to pay much". However, the BCG study suggests that fees for content "could help offset one to three years of anticipated declines in advertising revenue" (Boston Consulting Group, 2009b).

The Boston Consulting Group study, which claimed to be conducted independently of any media outlet, supports a hybrid model in which specialist content for niche markets is put behind a paywall, with general news remaining free. Senior vice president of BCG, Patrick Forth, was quoted as saying: "It's very encouraging in terms of the willingness of some segments of people to pay for some types of journalism. The research is not transformative of newspaper economics, but it is encouraging in that it says that the idea that people will never pay for online content is wrong”. Forth argues that 'hybrid models' such as the Wall Street Journal where non-subscribers are charged for some online content can work if they provide news that is not available for free on Web sites such as Google and Yahoo (Chessell, 2009).

According to the Boston Consulting Group research, 49 per cent of Australians say they will pay for online news that is either unique (such as breaking business or local news), timely (such as a news alert service), accessible from a mobile device, or gives them access to news archives. However, researchers point out that stated willingness to pay does not necessarily translate into actual payment. Only around 13 per cent of Australians currently pay for online news (Boston Consulting Group, 2009a, p. 17). Therefore, there is a substantial gap to bridge between media users' current habits and revenue targets, with substantial risk involved if media organisations over-estimate what users are prepared to pay.

The World Association of Newspapers appears to recognise that charging for content is not the sole or even the main solution for the media industry's woes. In a 2010 report titled 'Shaping the future of the newspaper', the association discussed nine revenue models being investigated in the industry worldwide, significantly listing 'paid content' last. The association's report notes that "the key to charging ... is that the content being charged for is unique, and cannot be accessed anywhere else" (World Association of Newspapers, 2010, p. 8).

Many editors and industry commentators are sceptical that, even if paywalls work for The New York Times and The Wall Street Journal, they may not work for media generally. In giving the 2009 Hugh Cudlipp Lecture in the UK, Editor of The Guardian Alan Rushbridger said:

I may be right for the Times of London and New York, but not for everyone. It may be right at some point for everybody in the future, but not yet. There is probably general agreement that we may all want to charge for specialist, highly-targeted, hard-to-replicate content. It's the 'universal' bit that is uncertain (Rushbridger, 2009, para. 29).

Therefore, charging for content appears to offer, at best, a partial business model for media, and comes in different forms and approaches. Reviewing a range of studies investigating paid media content identifies two variations of the model with two possible modes of implementation: (1) a full paywall requiring payment for all content, or (2) a hybrid model offering some content free plus fees for specialist content or high volume usage; with fees paid either by (a) subscription or (b) micro-payments. The first option is widely questioned in reports and analyses as cited, and evidence indicates it is unlikely to be successful except for specialist content such as financial information, business analysis, and sport. Analysis suggests that the second option offers a potential revenue stream for media, but is problematic in terms of determining which content will attract subscribers and which will 
not, and what level of fees will media users pay. Social media consultant Laurel Papworth refers to this hybrid approach as "freemiums" which work by attracting a large user base for free services which can then be offered premium services (Papworth, 2008).

In addition to studies recently undertaken, evidence that substantially increased revenue cannot be gained from subscription or micro-payments for content is also available in historical data on user spending on media. After remaining relatively constant through most of the $20^{\text {th }}$ century at around three per cent of disposable income, user spending on media increased to approximately four per cent of disposable income in the early $21^{\text {st }}$ century mainly because of the introduction of pay television, premium digital TV channels, downloadable music and satellite services (Pavlik, 2008, p. 166). While the trend is up, economic analysis suggests that this percentage is unlikely to increase further without putting pressure on household and business budgets.

A further philosophical argument against even partial paywalls was advanced by Guardian editor Alan Rushbridger. He questions whether journalism should exist in a 'walled garden' particularly quality journalism and deep analysis that are among the content most likely to go behind paywalls. Rushbridger notes that this might be good for business, but points that this would make some or a lot of journalism closed to many people, particularly those in lower socioeconomic groups (Rushbridger, 2009, para. 17).

Some suggest that a major trend in media could be in the opposite direction - towards free newspapers. In giving "10 tips on what newspapers can do for their print editions to survive", co-author of Blogging for Business Shel Holtz (2008) recommends improving the quality of publications and "provide all this free", generating income from other sources. Some of the other potential revenue streams are summarised in the following.

\section{Advertising 2.0}

It may seem confusing to posit the second alternative business model to media advertising as advertising. However, despite widespread gloom and doom in the media industry, advertising remains a major revenue source. While declining, display and classified advertising still outstrips other sources of revenue by a large margin. Furthermore, and even more importantly, advertising is evolving and new forms of advertising can potentially engage media users in new ways. Beyond early forms of internet advertising such as annoying 'pop ups' that block viewing of content, emergent advertising includes rich media (advertising involving video, sound and graphics even in online publications) and interactive applications including advertising in games (Interactive Advertising Bureau, 2008; Wells, Spence-Stone, Moriarty, \& Burnett, 2008). Also, with the development of Web 3.0 which involves the Semantic Web and increased capture of user profile data and clickstreams ${ }^{5}$, search engines will increasingly give way to 'recommendation engines' that distribute relevant advertising to targeted consumers. The evolution of Web $3.0^{6}$ and targeted advertising, referred to in the trade as "behavioural targeting" (Lee, 2009), is likely to raise concerns over privacy, but in this context it illustrates that advertising will continue to evolve and be a key source of revenue for media for some time to come. But, like paid content, it also is likely to be only part of business models in future.

\section{Public funding}

Public funding of media is seen by some embracing the political economy critique of media as providing a solution to the 'evils' of commercialisation of media and has been strongly advocated by Robert McChesney and John Nichols (2010) in their book The Death and Life of American Journalism. Curran (2010, p. 472) notes that McChesney and Nichols advocate “a massive intervention costing some \$35 billion" in the US alone. A more conservative 
approach is advocated by Leonard Downie and Michael Schudson (2009) in a lengthy Columbia Journalism Review article. They call for tax incentives; subsidisation of news media by philanthropic organisations and foundations; involvement in news reporting by universities; increased local news gathering by public broadcasting networks; taxes on telecommunications users to fund news media; financial support for trainee journalists; and encouragement of citizen journalism.

A number of countries have invested in at least one national publicly-funded media network such as Australia's ABC and the UK's BBC, as well as some partly government-funded media such as the Special Broadcasting Service (SBS) in Australia. With the financial crisis facing many media worldwide, national governments in several countries including the Netherlands and France, and one US State, have announced initiatives to extend support to commercial media. In January 2009, the president of France, Nicholas Sarkozy, announced subsidies for French media totalling $€ 600$ million (Euros) (almost $\$ 950$ million) over three years (“Sarkozy’s print media rescue plan”, 2009). However, France’s media subsidisation is comprised of an injection of government advertising and providing 18-year-olds free subscriptions to newspapers rather than direct cash handouts. In the Netherlands, the Minister for Media, Ronald Plasterk, launched a scheme in May 2009 to fully fund two young journalists on each of Holland's 30 daily newspapers for two years (Luft, 2009). In the US state of Washington where the Seattle Post-Intelligencer closed its print edition in April 2009 and continues as an internet publication only, Democratic governor Chris Gregoire has signed into law a 40 per cent tax break for newspaper printers and publishers ("Gov. Gregoire approves tax cut”, 2009).

However, public funding is problematic for several reasons. First, many traditional media organisations and are resistant to subsidisation. For instance, The Australian published an editorial in February 2009 strongly opposing subsidies and arguing that independence was essential for media organisations (“Online newspapers”, 2009). Second, democratically elected governments are likely to face challenges in directing substantial additional amounts of taxpayers' funds to media beyond existing funding of national broadcasters and some special interest and community media - some of which already struggle for adequate funding. New York Times media critic David Carr points out that public broadcasting networks such as PBS in the US receive only around 20 per cent of their budget from government funding, and notes that other high priority areas such as public schools, hospitals and infrastructure lack money. In addition to the competing demands of other social imperatives, the meltdown of global economies in 2008-2009 requiring massive injections of public funds to prop up financial systems will put pressure on government funds and taxation for some time. As desirable as this model is in the eyes of many reformers, it is unlikely to gain widespread public and political support in the current economic environment.

\section{Sales commissions}

Another potential business model suggested by consulting firms such as Deloitte, KPMG and PriceWaterhouseCoopers is commission revenue on sales of advertised products. Given that this approach has been suggested by some of the leading global business consulting firms, it is curious that it has not been explored more extensively. Major media with large classified sections advertising property, cars and other goods could have profited from this model before many customers slipped away to Craiglist, eBay and directly to the online sites of real estate agents, car companies, and so on. Looking back it seems incongruous that a newspaper advertising a house for sale or rent, for instance, offered no service other than the information printed on a page and sought no downstream relationship with potential buyers or property agents. Technology available since the mid-1990s would have enabled video tours of houses and apartments to be embedded in online newspaper property advertising, and viewer details 
to be captured, facilitating commissions when sales or rentals were made. The same principle could be applied to sales of cars, movie tickets and many other goods.

\section{Partnerships}

John Pavlik (2008) has identified four business models that he sees as likely to sustain future media including online media - advertising, subscription, e-commerce, and partnerships such as sponsorships, product placement and bundled product arrangements. Some basic applications of partnerships are being adopted such as television programs incorporating products as prizes. However, more sophisticated technology-enabled partnerships at the cutting edge of business today include opening the Application Programming Interface (API) of proprietary applications to third parties and sharing revenue. An example is e-Bay which, in addition to facilitating sales on its own site, allows members to trade on their own Web sites using e-Bay's software. Similarly, Amazon.com generates almost US\$500 million a quarter from Amazon API sales on third party sites and Salesforce generates 40 per cent of its revenue from external sites (Papworth, 2008). Few media organisations have opened up their APIs to partner organisations. On a smaller scale, partnerships can also utilise widgets which are small standalone software applications (or applets) that can be embedded into third party sites. For instance, a widget displaying sports news headlines in a small window could be embedded in many sites of willing partners and could result in increased traffic to main media sites, as well as increased brand awareness and audience reach.

\section{Diversification into consumer products}

The 2005 Deloitte Technology, Media and Telecommunication report on the television industry proposed options including operating as 'gateways' to the media market at large, becoming service providers, or diversifying into consumer products. While a number of newspapers and magazines have produced related media products such as books (e.g. good food, dining, gardening and home decorating guides), these could be substantially expanded to other topics and include DVDs and specialist Web site spin-offs. Despite often having the largest team of researchers and information gatherers in many areas, newspapers have mostly missed the boat in production of local and specialist directories of services and events which are typically produced by niche publishers in most cities and industries. Furthermore, horizontal diversification does not need to be restricted to media-related products. Major newspaper, magazine, TV and radio network brands could look further afield for revenue streams. As music bands, sporting clubs and teams, and others have shown, products ranging from clothing lines to holiday tours can be sold off the back of a strong brand.

In its 2006 warning that newspapers are an "endangered species” unless they develop new revenue streams, The Economist cited a profitable Norwegian newspaper that set up an online slimming club for readers (McKnight \& O’Donnell, 2008, para. 10). Major media brands could also be leveraged to sell mobile/cell phone services (e.g. with exclusive ringtones from popular programs and photos of its major stars as screen savers); food products, wine, clothing labels, luggage, holidays, and so on. Some media have been tried to diversify, but many remain one product companies.

As well as physical products, significant revenue can be generated from virtual products which social media consultant Laurel Papworth (2008) estimates as a US\$2 billion a year market. These range from virtual fluffy pixel toys in Facebook to virtual property sold by Second Life. According to Papworth (2009), real-time online events are also a product that can generate revenue in future. She says real-time online events have several compelling appeals for users and can be highly profitable. On the cost side, they are usually much less expensive to stage than physical events. On the benefits side, they are synchronous (i.e. happening now, not delayed), one-time only (if you are not there you miss out), and they are 
not subject to time shifting, place shifting or format shifting. She gives examples such as realtime chat with celebrities and experts, online poker tournaments, and Second Life concerts. Real-time online events could also be a B2B and B2 $\mathrm{C}^{7}$ product, featuring talks by business leaders or technical experts such as software developers, medical researchers or environmental scientists.

\section{Archive re-use and repurposing}

One product 'under the noses' of media organisations is their archives. Major newspapers, some of which have been in existence for a century or more, hold vast amounts of information as well as photographic material. Not only can this be sold for historical or personal use, but it can be repurposed. KPMG has identified "potentially huge" business opportunities in media archives which include billions of articles, reports, photos, reels of film, sound files, and historical accounts of important events over a century or more in some cases (2007, p. 4). Archive content could be re-used and repurposed for research services, corporate art (such as photos of major events, personalities and historic occasions), 'reality' footage for the movie industry, and even fashion and home decoration.

\section{The Attention Economy}

One potential new business model related to advertising but taking a significantly different approach is based on what is termed the Attention Economy, a concept first mooted by Herbert Simon (1971) and advanced by business analysts Michael Goldhaber (1997), Thomas Davenport and Thomas Beck (2001), and more recently by Alex Iskold (2006) and Iskold writing with Richard MacManus (2007). The term, borrowed from 1970s social science (Rushkoff, 2003, p. 28), puts focus firmly on the core element of what media organisations, content producers and marketers want and need in order to sustain their businesses. The Attention Economy is about the value of people's attention. In the so-called 'information age' characterised by 'information overload' according to many scholars (e.g. Schudson, 2003), attention is increasingly hard to get. Therefore it is valuable. But, traditionally, neither media nor advertisers have rewarded people for their attention. Advertisers have paid the medium for its space or time when the real product being purchased is the attention of media users.

There are three key features of an Attention Economy approach. First, in this model advertisers would pay a proportion of advertising fees to media users for their attention either directly in cash or in credit points that they could use to buy products or services. The balance would be paid to media for their space and time. Second, media users would have the option to receive advertising or not and to select categories of advertising that they receive. Iskold and MacManus who write about this model extensively say "the key ingredient of the attention game is relevancy" (2007, para. 6). This model could well be called relevancy advertising and is a more sophisticated approach than 'behavioural targeting' advocated by some marketers which simply uses data to achieve their own objectives (Lee, 2009).

User selection of relevant content could be built in as a function in Web browsers, or occur via a third-party plug-in, offering a benefit to media users. A user could set up their profile and check boxes either for 'no advertising', or select subjects such as 'travel' and then specific topics in sub-menus such as 'New Zealand'. Once this was done, a user would only receive advertising on that topic. Profiles could be changed so that users who come into the market for a holiday could invite advertising from airlines and travel operators and then deactivate this advertising once they have selected their product. Users could also record their name, age, gender and other personal details such as tastes, preferences and interests in their profile. This raises the important issues of privacy and data security, and a key element of the 
Attention Economy approach proposed is responsible industry self-regulation under voluntarily adopted standards, or regulation.

An Attention Economy approach provides benefits to both media users and advertisers. A combination of payment for their attention and some control over their data and advertising they receive rather that enduring intrusive and irrelevant advertising is likely to encourage audiences back to media, as well as provide more efficient methods of marketing. With optout mechanisms, advertisers would have access to fewer media users in total, but those to whom they have access would be qualified prospects in marketing terms with an interest in the products or services advertised. Furthermore, if effective privacy and security measures are put in place, advertisers could in future have access to media users' information across the entire internet, a vast and valuable store of market research and intelligence which media organisations could collect and sell as an additional revenue stream (see next point).

\section{Data}

The increasing amount of data on media users and their interests, needs, and patterns of information search and purchasing available from Web statistics, search engines, tracking of clickstreams, and other data available as Web 3.0 emerges, offers new opportunities to media and businesses targeting potential consumers of their products and services. In a report titled 'The Impact of Digitalization', KPMG consultant, Lars Mouritzen says that "a scramble to earn the right to capture transactional data seems likely” (2007, p. 33). In a paper based on its 'Marketing \& Media Ecosystem 2010' study, Booz Allen Hamilton recommends that marketers "ruthlessly build consumer insights" by capturing user data on the internet (Rasmussen, Ude \& Landry, 2007, p. 12). Use of the word 'ruthlessly' suggests that tensions are likely to develop between businesses collecting and using personal data and human rights and concerns for privacy. One would hope that industry will not "ruthlessly" build 'consumer' insights through collecting and exploiting data gained from the internet, but rather act responsibly and sensitively. Failure to do so is likely to lead to government regulation which is unlikely to be in the industry's interests long-term.

The data tracking and collection capabilities of the Web, and particularly Web 3.0, are a significant concern for social science and humanities scholars such Jeffrey Chester (2006) and John Battelle (2005). Industry self-regulation efforts to date in relation to data collected on the internet do not instil confidence. In 2008, the Interactive Advertising Bureau (IAB) proposed new privacy guidelines for online advertising which call for companies to notify internet users when data is being collected for targeted advertising and to provide links to privacy policies (Mills, 2008). However, the IAB draft guidelines fall well short of what the US Federal Trade Commission has sought. In its proposed privacy principles unveiled in December 2007, the FTC called for a "clear, consumer-friendly, and prominent statement" that data is being collected for targeted ads. The IAB approach allows notices to be buried anywhere in a Web site such as in a 'Privacy Policy' page many clicks away from the home page. Also, the FTC has called for consumers to be able to opt out of targeted ads. The IAB's 2008 draft guidelines favour directing consumers to other sites where they can opt out of having their data gathered and used for advertising. Groups such as the Center for Digital Democracy and the Electronic Privacy Information Center say the advertising industry's guidelines go nowhere near far enough and provide little real protection for media users (Mills, 2008). However, if the industry acts responsibly, it may realise that data is its most valuable product, leading to the development of whole new revenue streams and diversification beyond traditional advertising.

In addition to supporting charges for content, taxes on telecommunications users, and new forms of advertising including cross-media advertising, the World Association of 
Newspapers (2010) report lists other potential revenue streams being investigated by media organisations as:

- Endowments,

- Memberships and syndication such as the operations of GlobalPost.com;

- Foundation grants;

- Establishment of media as not-for-profit entities; and

- Creation of hyperlocal Web sites, newspapers and blogs.

Some of these are dependent on the taxation laws of each country and others such as hyperlocal Web sites are already being established 'under the noses' of traditional media organisations by independent operators (e.g. www.StreetCorner.com.au). Also, many of these approaches also need further development before they offer a sustainable business model.

\section{Conclusions}

Empirical data on media audiences and revenue show that 'Rome is burning' and that there is an urgent imperative to develop new sustainable media business models. Whether current media organisations will be reborn like the mythical Phoenix to live another millennium, or whether we are witnessing a Nero-like approach to the 'Fall of Rome' as Mark Scott suggests, will depend on management decisions over the next few years.

At this stage, no consensus or even widespread agreement has emerged on any alternative business model, and many of those proposed need further development and analysis. In that process, economic feasibility and market acceptance need to be sensitively balanced.

Most discussion here has focussed on paywalls because of major initiatives currently being launched or discussed worldwide. However, consumer resistance identified in surveys and the open source culture of the internet suggest that charges for content will provide a supplementary revenue stream for high value premium content, not a widely-applicable business model. Similarly, competing high priority demands for public funding, combined with high levels of debt faced by many countries following the global financial crisis, mean that large-scale government support, the next most discussed alternative model, is unlikely in most Western democracies.

However, the diversity of types of media content and media users' needs and preferences indicate that a 'one size fits all approach' is unlikely to ensure media survival - or, better, reform and renewal. As David Carr (2010) suggests, the best way forward may be a hybrid model involving diversification to create multiple revenue streams developed to suit each medium and its operations.

\section{References}

Anderson, C. (2006). The long tail. New York: Hyperion.

Anheier, H., \& Raj Isar, Y. (Eds.). (2008). The cultural economy. London and Thousand Oaks, CA: Sage.

Audit Bureau of Circulations. (2010). Newspaper circulation. Retrieved April 30, 2010, from http://mumbrella.com.au/national-and-metro-newspapers-in-biggest-ever-decline-18075\#more18075

Australian Communications and Media Authority. (2007, December). Media and communications in Australian families 2007. Report of the Media and Society Research Project. Canberra: Author. 
Bailly, N. (2009, November 13). News Corp COO ponders overhaul of WSJ's paywall system, others still don't think it will work. editorsweblog.org. Retrieved January 23, 2010, from http://www.editorsweblog.org/multimedia/2009/11/news_corp_coo_ponders_overhaul_of_wsjs_p. php

Battelle, J. (2005). The search: How Google and its rivals rewrote the rules of business and transformed our culture. Boston, MA: Penguin Group, Portfolio, USA and Nicholas Brealey.

Bell, E. (2008, October 14). Address to Polis Journalism and Society Think Tank, London.

Boler, M. (Ed.). (2008). Digital media and democracy: Tactics in hard times. Cambridge, MA: MIT Press.

Boston Consulting Group. (2009a). Willingness to pay for news online: Key findings from an international survey. Report by BCG Technology, Media \& Telecommunications, November. Author.

Boston Consulting Group. (2009b). News for sale: Charges for online news are set to become the norm as most consumers say they are willing to pay. Press release, November 16. Author. Retrieved January 24, 2010, from http://www.bcg.com/media/PressReleaseDetails.aspx?id=tcm:12-35297

Business Week Stock Quote \& Company Profile. (2010). NEWS CORP-CLASS B (NWS: NASDAQ), 19 January. Retrieved January 24, 2010, from http://investing.businessweek.com/research/stocks/snapshot/snapshot.asp?symbol=NWS

Canadian Journalism Project. (2009). Conference report: The future of journalism, Cardiff, Wales, September 9-10. Author. Retrieved April 27, 2010, from http://jsource.ning.com/profiles/blogs/conference-report-the-future

Carr, D. (2010). Government funding cannot save journalism. The Nation. Retrieved April 27, 2010, from http://www.thenation.com/doc/20100419/carr_video

Chen, P., \& Walsh, L. (2008). E-election 2007? Political competition online. In M. Simms \& J.

Warhurst (Eds.), Kevin 07: The 2007 Australian federal election. St Lucia, Brisbane: Queensland

University Press.

Chessell, J. (2009, November 18). Net users warm to paid content model. The Australian. Retrieved January 24, 2010, from http://www.theaustralian.com.au/australian-it/internet-users-willing-topay-small-fee-for-online-news-content/story-e6frgakx-1225799135054

Chester, J. (2006, October 16). Google, YouTube and you. The Nation. Retrieved August 11, 2008 from http://www.thenation.com/doc/20061030/chester

Crawford, K. (2005). Adaptation: Tracking the ecologies of music and peer-to-peer networks. Media International Australia, 114, February, 30-53.

Crawford, H. (2009, December 15). Journalism and freedom. Retrieved January 22, 2010, from http://news.ninemsn.com.au/Blog.aspx?blogentryid=547597\&showcomments=true

Curran, J. (2010). Future of journalism. Journalism Studies, 11(4), 464-476.

Davenport, T., \& Beck, J. (2001). The attention economy: Understanding the new currency of business. Cambridge, MA: Harvard Business School Press.

Day, M. (2009, October 19). Time for a content reality check. The Australian blogs. Retrieved January 22, 2010, from

http://blogs.theaustralian.news.com.au/markday/index.php/theaustralian/comments/time_for_a_co ntent_reality_check?source $=$ cmailer

Deloitte. (2005). Television networks in the $21^{\text {st }}$ century: Growing critical mass in a fragmenting world. New York and Sydney: Deloitte Technology, Media and Telecommunications Group.

Deuze, M. (2007). Media work. Malden, MA and Cambridge, UK: Polity Press.

Downie, L., \& Schudson, M. (2009). The reconstruction of American journalism. Columbia Journalism Review, October 19. Retrieved April 28, 2010, from http://www.cjr.org/reconstruction/the_reconstruction_of_american.php?page=all

du Gay, P., \& Pryke, M. (Eds.). (2000). Cultural economy. London: Sage.

Dyer, G. (2009, May 11). Newspaper DeathWatch: UK dailies flatline. Crikey, Media, Arts, Sport, item 26. Retrieved May 30, 2009, from

http://www.crikey.com.au/Email/Preview/DailyEmailPreview.aspx?pid=bb9df487-cb5f-4bd3bf37-c45bee513bf5

Este, J., Warren, C., Connor, L., Brown, M., Pollard, R., \& O’Connor, T. (2008). Life in the clickstream: The future of journalism. Sydney: Media Arts \& Entertainment Alliance. Retrieved January 26, 2009, from http://www.alliance.org.au/documents/foj_report_final.pdf 
Foley, S. (2007, June). Integrated newsrooms, PANPA Bulletin, Pacific Area Newspaper Publishers Association.

Fouquet, H. (2009, January 30). Sarkozy bid to boost press may fail to save titles. Bloomberg. Retrieved January 24, 2010, from http://www.bloomberg.com/apps/news?pid=20601102\&sid=aeflsW5JrItc\&refer=uk

Free TV Australia. (2010). Advertising revenue for commercial television networks July to December 2009. Media release, 29 January. Retrieved February 1, 2010 from http://www.freetv.com.au/media/News-Media_Release/PR13_Revenue_figures_-_Jul__Dec_09.pdf?source=cmailer

Goldhaber, M. (1997). The attention economy and the net. First Monday, Vol, 2, No. 4. April. Retrieved March 23, 2010, from http://firstmonday.org/htbin/cgiwrap/bin/ojs/index.php/fm/issue/view/79

Gov. Gregoire approves tax cut for Washington State newspapers. (2009, May 12). The Seattle Times. Retrieved January 24, 2010, from http://seattletimes.nwsource.com/html/localnews/2009212482_apwanewspapertaxcuts.html

Harris, E. (2009, May 19). Turning to politicians to prop up our newspapers. Crikey. Retrieved May 20, 2009 from Media Monitors, Sydney.

Hartigan, J. (2009). Speech to the National Press Club, Canberra, Australia, July 1 . Retrieved July 2, 2009, from http://www.news.com.au/heraldsun/story/0,21985,25718006-661,00.html

Holtz, S. (2008, November 20). Ten changes that could save print newspapers. A Shel of my Former Self. Blog post. Retrieved November 24, 2008, from http://blog.holtz.com/index.php/weblog/ten_changes_that_could_save_print_newspapers/

Interactive Advertising Bureau. (2008). Measurement guidelines. New York: Author. Retrieved November 29, 2008, from http://www.iab.net/iab_products_and_industry_services/508676/508722

Iskold, A. (2006, September 19). From attention economy to attention architecture. Alex Iskold Technology Blog. Retrieved May 12, 2008, http://alexiskold.wordpress.com/2006/09/19/fromattention-economy-to-attention-architecture/

Iskold, A., \& MacManus, R. (2006, November 14). The road to the Semantic Web. Blog article. Retrieved March 22, 2010, from http://www.readwriteweb.com/archives/semantic_web_road.php

Iskold, A., \& MacManus, R. (2007, March 1). The attention economy: An overview. ReadWriteWeb blog. Retrieved May 9, 2008 http://www.readwriteweb.com/archives/attention_economy_overview.php

Jarvis, J. (2010, January 17). The cockeyed economic of metering reading. BuzzMachine. Retrieved January 22, 2010, from http://www.buzzmachine.com/2010/01/17/the-cockeyed-economics-ofmetering-reading/?source $=$ cmailer

Jenkins, H. (2006). Convergence culture: Where old and new media collide. New York: New York University Press.

Kruger, C. (2010, May 14). Domestic newspapers buck global trend. www.smh.com.au. Retrieved May 15, 2010, from http://www.smh.com.au/business/domestic-newspapers-buck-global-trend20100513-v1rb.html

KPMG. (2007, January). The impact of digitalization: A generation apart. KPMG International Information, Communication and Entertainment Practice. Retrieved November 14, 2008, from http://www.kpmg.com/cn/en/issuesandinsights/articlespublications/pages/impact-digitalization-o200701.aspx

Leadbeater, C. (2007). We-think: Why mass creativity is the next big thing. Online edition Retrieved January 22, 2009 from http://www.wethinkthebook.net/cms/site/docs/charles\%20full\%20draft.pdf

Lee, J. (2009, April 20). Web users under the microscope. Sydney Morning Herald, p. 22.

Lessig, L. (2001). The future of ideas. New York: Random House.

Lessig, L. (2004). Free culture: How big media uses technology and the law to lock down culture and control creativity. New York: Penguin.

Liedtke, M. (2009, September 1). Freedom Communications files for bankruptcy. Editor \& Publisher. Retrieved September 2, 2009, from http://www.editorandpublisher.com/eandp/news/article_display.jsp?vnu_content_id=1004008192 \&source $=$ cmailer

Locke, C., Levine, R., Searles, D., \& Weinberger, D. (2000). A cluetrain manifesto: The end of business as usual. New York: Perseus Books (Available online at http://cluetrain.com/book/apocalypso.html) 
Luft,O. (2009, May 14). Dutch government to pay salaries of 60 newspaper journalists. The Guardian. Retrieved January 24, 2010, from http://www.guardian.co.uk/media/2009/may/14/dutch-journalists-government-payout

Macnamara, J. (2008). E-electioneering: Use of new media in the 2007 Australian federal election. In E. Tilley (Ed.), Power and Place: ANZCA 2008: Refereed proceedings of the Australian and New Zealand Communication Association Conference 2008, 9-11 July. Wellington, New Zealand: Massey University. Retrieved March 10, 2010, from http://www.massey.ac.nz/?aaac11238s

Macnamara, J. (2010). The $21^{\text {st }}$ century media (r)evolution: Emergent communication practices. New York: Peter Lang.

McChesney, R., \& Nichols, J. (2010). The death and life of American journalism: The media revolution that will begin the world again. New York: Nation Books.

McKnight, D., \& O’Donnell, P. (2008, September 3). The winter of journalism's content. The Australian online. Retrieved January 9, 2009, from http://www.theaustralian.news.com.au/story/0,25197,24283745-13480,00.html

Meyer, P. (2008). The elite newspaper of the future', American Journalism Review, OctoberNovember. Retrieved March 1, 2009, from http://www.ajr.org/Article.asp?id=4605

Mills, E. (2008, February 24). Don't like targeted ads? Opt out, says online ad group. CNET News. Retrieved October 24, 2008, from http://news.cnet.com/8301-10784_3-9877604-7.html

Montgomery, K. (2009). Generation digital: Politics, commerce, and childhood in the age of the internet. Cambridge, MA: MIT Press.

Mouritzen, L. (2007, January). Recommendations rock. In KPMG, The impact of digitalization - a generation apart, report by KPMG International Information, Communication and Entertainment Practice (pp. 30-33). Retrieved November 14, 2008, from http://www.kpmg.nl/\%5CDocs/Corporate_Site/Publicaties/Impact_Digitalization.pdf

Murdoch, R. (2005, April 13). Speech to the American Society of Newspaper Editors, New York. Retrieved April 25, 2007 from http://www.newscorp.com/news/news_247.html

National newspapers in biggest ever decline (and mags).(2010, February 12). mUmBRELLA. Retrieved February 13, 2010, from http://mumbrella.com.au/national-and-metro-newspapers-inbiggest-ever-decline-18075\#more-1807

Newspaper Association of America. (2008). Total paid circulation. Retrieved January 22, 2009, from http://www.naa.org/TrendsandNumbers/Total-Paid-Circulation.aspx

Newspaper Association of America. (2010). Advertising expenditures. Retrieved April 27, 2010, from http://www.naa.org/TrendsandNumbers/Advertising-Expenditures.aspx

Online newspapers: Have faith in quality, not government subsidies. (2009, February 10). The Australian. Editorial, p. 15.

O’Reilly, T. (2005, September 30). What is web 2.0: Design patterns and business models for the next generation of software. O'Reilly blog. Retrieved June 20, 2008, from http://www.oreillynet.com/pub/a/oreilly/tim/news/2005/09/30/what-is-web-20.html

Papworth, L. (2008). Social media monetarisation and revenue. Blog post, 27 September. Retrieved February 3, 2009, from http://laurelpapworth.com/social-media-monetization-and-revenue/

Papworth, L. (2009, January 13). Revenue: Events in social networks. Blog post. Retrieved February 3, 2009 from Papworth http://laurelpapworth.com/revenue-events-in-social-networks/

Pavlik, J. (2008). Media in the digital age. New York: Columbia University Press.

Pérez-Peña, R. (2007, September 18), Times to stop charging for parts of its web site, New York Times. Retrieved October 16, 2008, from http://www.nytimes.com/2007/09/18/business/media/18times.html?ex=1347768000\&en=88011ab 45717e39d\&ei=5124\&partner=permalink\&exprod=permalink

Pérez-Peña, R. (2009, October 6), US newspaper circulation falls 10\%, New York Times. Retrieved January 23, 2010, from http://www.nytimes.com/2009/10/27/business/media/27audit.html

Poster, M. (1995). The second media age. Cambridge, UK: Polity.

Prahalad, C., \& Ramaswamy, V. (2004). The future of competition: Co-creating unique value with customers. Boston, MA: Harvard Business School Press.

PriceWaterhouseCoopers. (2009). Moving into multiple business models: Outlook for newspaper publishing in the digital age. Report of online survey of 4,900 consumers in seven countries. Author. Retrieved January 22, 2010, from http://www.pwc.com/gx/en/entertainmentmedia/publications/outlook-newspaper-publishing-in-digital.jhtml 
Radoff, J. (2009, November 30). Brief history of paywalls. Jon Radoff: Internet Entrepreneur 2.0 blog. Retrieved January 23, 2010, from http://radoff.com/blog/2009/11/30/a-brief-history-ofpaywalls/

Rasmussen, A., Ude, C., \& Landry, E. (2007). HD marketing 2010: Sharpening the conversation. Booz Allen Hamilton. Retrieved November 14, 2008 from http://www.boozallen.com/media/file/HD_Marketing_2010.pdf

Rheingold H. (2008a). Using participatory media and public voice to encourage civic engagement. In W. Bennet (Ed.), Civic life online: Learning how digital media can engage youth (pp. 97-118). Cambridge, MA: MIT Press.

Roy Morgan Research. (2007, June). Finding 4182. Sydney: Author. Retrieved May 26, 2008, from www.roymorgan.com

Rushbridger, A. (2009). Does journalism exist? Hugh Cudlipp Lecture, London, 25 January. Retrieved January 27, 2009, from http://www.guardian.co.uk/media/2010/jan/25/cudlipp-lecturealan-rusbridger?source $=$ cmailer

Rushkoff, D. (2003). Open source democracy: How online communication is changing offline politics. London: Demos.

Sarkozy's print media rescue plan: Newspaper subscriptions for teens. (2009, January 24). Radio France Internationale. Retrieved January 24, 2010, from http://www.rfi.fr/actuen/articles/109/article_2718.asp

Schudson, M. (2003). Click here for democracy: A history and critique of an information-based model of citizenship. In H. Jenkins \& D. Thorburn (Eds.), Democracy and new media (pp. 49-60). Cambridge, MA: MIT Press.

Scott. M. (2009). The fall of Rome: Media after empire. A.N. Smith Memorial Lecture in Journalism 2009. University of Melbourne, 14 October. Retrieved January 25, 2010, from http://www.abc.net.au/corp/pubs/media/s2714080.htm

Simon, H. (1971). Designing organisations for an information-rich world. In M. Greenberger (Ed.), Computers, communication and the public interest (pp. 37-72). Baltimore, MD: Johns Hopkins Press.

Simons, M. (2010, January 13). Will Australians pay for content online - new survey data. Crikey.com blogs. Retrieved January 22, 2010, from http://blogs.crikey.com.au/contentmakers/2010/01/13/will-australians-pay-for-content-online-newsurvey-data/

Steffens, M. (2008, August 27). Fairfax Media to cut 550 jobs in Australia, NZ. Sydney Morning Herald, Business Day. Retrieved November 27, 2009, from http://www.smh.com.au/business/fairfax-media-to-cut-550-jobs-in-australia-nz-20080826433v.html

Steffens, M. (2009, April 1). Ad fall at papers is less than 1 per cent. Sydney Morning Herald, Business Day. Retrieved April 30, 2010, from http://www.smh.com.au/business/ad-fall-at-papersis-less-than-1-20090331-9ic6.html

Tapscott, D. \& Williams, A. (2006). Wikinomics. How mass collaboration changes everything. New York: Penguin.

The Atlantic drops pay wall. (2008, January 22). Atlantic Monthly. Retrieved January 23, 2010, from http://www.theatlantic.com/doc/200801u/editors-note

The promiscuity problem. (2009), December 3). The Economist. Retrieved January 14, 2010, from http://www.economist.com/world/britain/displayStory.cfm?story_id=15017453\&source=cmailer

TMZ. (2009, June 25). Michael Jackson - Cardiac arrest. Web site post. Retrieved July 28, 2009 from http://www.tmz.com/2009/06/25/michael-jackson-rushed-to-the-hospital/

Van Dijck, J. Nieborg, D. (2009). Wikinomics and its discontents: A critical analysis of Web 2.0 business manifestos. New Media \& Society,11(5), 855-874.

Wang, J. (2009). New media technology and new business models: Speculations on 'post-advertising' paradigms. Media International Australia, 133, 110-119.

Wells, W., Spence-Stone, R., Moriarty, S., \& Burnett, J. (2008). Advertising principles and practice (Australian ed.). Frenchs Forest, Sydney: Pearson Education Australia.

World Association of Newspapers. (2010). New revenue models for newspaper companies, Vol. 9, Report No. 2. Retrieved April 9, 2010, from http://www.wanpress.org/article18438.html?source=cmailer 
1 Paywalls block access to a Web page until payment is made. Digital mechanisms (code) in the sites present a window requiring subscription of pay per use.

2 The term Web 2.0 is widely attributed to Tim O’Reilly who used it as the theme of a conference in 2004 referring to a second generation of Web-based services that feature openness for collaboration and interactivity (Boler, 2008, p. 39; O’Reilly, 2005).

3 'Walled gardens' in the context of the internet refer to Web sites that are closed to the general public offering exclusive information services to subscribers or members only.

4 Jon Radoff developed the highly successful computer game Legends of Future Past, one of the first MMORGPS (Massively Multiplayer Online Role-Playing Game).

5 Clickstreams refer to the invisible but traceable trails that internet users leave. Mouse clicks on Web sites can be tracked to identify where internet users go and what information they access.

6 Web 3.0, also known as the Semantic Web, will not look much different to the untrained observer, but will introduce several substantial innovations under the surface including tagging of Web content with computer code that will make finding documents much faster and more precise than current techniques that rely on embedded links and searching for key words that appear in documents. Also, increased amounts of users' personal and profile information will be captured to facilitate 'targeting' of users with relevant information by 'recommendation engines' that will steadily replace search engines (see Iskold \& MacManus, 2006).

7 B2B is an abbreviation of business-to-business and B2C stands for business-to-consumer.

\section{Published Reference:}

Macnamara, J. (2010). Remodelling media: The urgent search for new media business models. Media International Australia, 137, November, 20-35.

* Jim Macnamara PhD, MA, FPRIA, FAMI, CPM, FAMEC is Professor of Public Communication at the University of Technology Sydney and Director of the Australian Centre of Public Communication, positions he took up in 2007 after a 30-year professional career spanning journalism, public relations and media research. He is the author of 12 books including The $21^{\text {st }}$ Century Media (R)evolution: Emergent Communication Practices published by Peter Lang, New York in 2010 and Public Relations Theories, Practices, Critiques published by Pearson Australia in 2012. 